\title{
The Role of Interleukin-6 Polymorphism (rs1800795) in Prostate Cancer Development and Progression
}

\author{
JANA JUREČEKOVÁ ${ }^{1}$, HENRIETA DROBKOVÁ ${ }^{2,3}$, MIROSLAVA ŠARLINOVÁ ${ }^{1}$, EVA BABUŠÍKOVÁ ${ }^{4}$, \\ MONIKA KMEŤOVÁ SIVOŇOVÁ ${ }^{4}$, TATIANA MATÁKOVÁ ${ }^{1,4}$, JÁN KLIMENT ${ }^{2}$ and ERIKA HALAŠOVÁ ${ }^{1,3}$ \\ ${ }^{1}$ Department of Molecular Medicine, Jessenius Faculty of Medicine in Martin, \\ Biomedical Center Martin, Comenius University in Bratislava, Martin, Slovakia; \\ ${ }^{2}$ Department of Urology, Jessenius Faculty of Medicine and University \\ Hospital Martin, Comenius University in Bratislava, Martin, Slovakia; \\ ${ }^{3}$ Department of Medical Biology, Jessenius Faculty of Medicine in Martin, \\ Comenius University in Bratislava, Martin, Slovakia; \\ ${ }^{4}$ Department of Medical Biochemistry, Jessenius Faculty of Medicine in Martin, \\ Comenius University in Bratislava, Martin, Slovakia
}

\begin{abstract}
Background/Aim: Interleukin-6 is an important modulator of inflammation, which is one of the factors involved in prostate cancer. The aim of the study was to evaluate the possible association of the IL-6 -174 polymorphism (rs1800795) with the risk of prostate cancer development and progression. Materials and Methods: The study population consisted of 446 prostate cancer patients, 377 benign prostatic hyperplasia $(B H P)$ patients and 276 healthy men. Genotyping was performed by PCR-RFLP analysis. IL-6 plasma levels were measured by the ELISA method. Results: The GC genotype $(O R=0.61, p=0.005)$ and $C$ allele $(O R=0.8, p=0.04)$ of the IL-6 -174 polymorphism were significantly associated with prostate cancer. No genotype was associated with BHP. IL-6 plasma levels were significantly increased in prostate cancer patients compared to both healthy men $(p=0.02)$ and BHP patients $(p=0.008)$. No significant differences were observed in IL-6 plasma levels in connection with IL-6 -174 genotypes. Conclusion: The IL-6 -174 polymorphism was significantly associated with prostate cancer in Slovak patients.
\end{abstract}

Interleukin-6 (IL-6) is a multifactorial pro-inflammatory cytokine belonging to the family of IL-1 cytokines. It is produced by different types of cells, including activated macrophages, monocytes, fibroblasts, activated T lymphocytes

Correspondence to: Henrieta Drobková, Department of Urology, Jessenius Faculty of Medicine and University Hospital Martin, Kollarova 6, 03601 Martin, Slovakia. Tel: +42 1432633483, e-mail: henrieta.drobkova@gmail.com

Key Words: Interleukin-6, prostate cancer, polymorphism, rs 1800795 . and B lymphocytes, endothelial cells, as well as cancer cells. IL-6 mediates several important physiological functions including control of the acute phase response during inflammation, production of adhesion molecules and induction of secretion of other inflammation mediators such as tumor necrosis factor. IL-6 may also mediate carcinogenesis by several mechanisms, including stimulation of cell proliferation, reduction of apoptosis, alteration of enzymes involved in tumor invasion and promotion of bone metastases (1). IL-6 is also one of the factors that may contribute to increased growth of prostate cancer cells in the absence of androgens by activation of androgen receptor (2). IL-6 can also contribute to the transformation of benign prostate cells into malignant cells and promote epithelial mesenchymal transition (3). The levels of IL-6 also correlate with prostate tumor burden, serum prostatespecific antigen and metastasis (4).

The human $I L-6$ gene is located at the short arm of chromosome 7 (7p15-21) and includes 5 exons and 4 introns (5). The expression of $I L-6$ gene as well as the concentration of IL-6 might be influenced by the presence of polymorphic sites in the gene. Single nucleotide polymorphisms in the promoter may result in alterations in expression and functional activity of IL-6. Increased expression of IL-6 and its receptor was detected in malignant prostate tissue and high-grade prostatic intraepithelial neoplasia lesions (6). The G/C transition in IL-6 gene (rs1800795) is suggested to be associated with altered production of IL- 6 , because of its localization in the promoter region where gates GATA1 access (7). The polymorphism is also located in region with partial sequence homology with the Smad4-binding element. It is supposed that the $\mathrm{C}$ allele may bind Smad4 more effectively and inhibit $I L-6$ transcription (8). The $\mathrm{G}$ allele was found to be the higher $I L-6$ expressing variant (5). 
The aim of the study was to analyze the possible association of the promoter polymorphism at position -174 (rs1800795) of the $I L-6$ gene and the risk of prostate cancer development and progression in a group of Slovak prostate cancer patients.

\section{Materials and Methods}

Study population. The present study included 446 patients with histologically verified prostate cancer, 377 patients with benign prostatic hyperplasia (BHP) and 276 healthy men. Patients were recruited at the Department of Urology, University Hospital Martin in Slovakia, during the time period 2005-2017. Healthy volunteers were randomly selected from men that attended routine urological examinations and who did not have a cancer history as well as any prostate disease. The study was approved by the Ethics Committee of Comenius University in Bratislava, Jessenius Faculty of Medicine in Martin and both patients and healthy men gave their informed consent to participate in the study. The clinical characteristics of the subjects are summarized in Table I.

Genotyping. Genomic DNA was isolated from whole blood samples using Wizard ${ }^{\circledR}$ Genomic DNA Purification Kit (Promega, Madison, WI, USA) and stored at $-20^{\circ} \mathrm{C}$ until genotype analysis. The polymorphism in the promoter region of $I L-6$ gene, $-174 \mathrm{G} / \mathrm{C}$ (rs1800795), was determined by polymerase-chain reaction-restriction fragment length polymorphism (PCR-RFLP) analysis. The DNA fragments were amplified in a $12 \mu \mathrm{l}$ reaction mixture containing $1 \mu \mathrm{l}$ of genomic DNA $(0.1 \mu \mathrm{g} / \mu \mathrm{l}), 0.4 \mu \mathrm{l}$ of each primer $(25 \mu \mathrm{mol} / \mu \mathrm{l})$, $6 \mu \mathrm{l}$ of DreamTaq Green PCR Master mix (2x) and $4.2 \mu \mathrm{l}$ of DNase free water. The primer sequences used for detection of $I L-6-174 \mathrm{G} / \mathrm{C}$ polymorphism were: F 5'-ATG CCA AGT GCT GAG TCA CTA-3', R 5'-GGA AAA TCC CAC ATT TGA TA-3'. The PCR amplification conditions for $I L-6-174 \mathrm{G} / \mathrm{C}$ were as follows: $5 \mathrm{~min}$ initial denaturation at $94^{\circ} \mathrm{C}$, and 40 cycles of $30 \mathrm{sec}$ at $94^{\circ} \mathrm{C}, 45 \mathrm{sec}$ at $52.8^{\circ} \mathrm{C}$ and $1 \mathrm{~min}$ at $72^{\circ} \mathrm{C}$, followed by a final elongation at $72^{\circ} \mathrm{C}$ for $7 \mathrm{~min}$. After amplification, $226 \mathrm{bp}$ PCR products were digested with NIaIII restriction enzyme for $15 \mathrm{~min}$ at $37^{\circ} \mathrm{C}$. Digested products were separated by electrophoresis on $2 \%$ agarose gel and visualized by ethidium bromide staining. When the $\mathrm{C}$ allele was found at the -174 position, two fragments of 117 and $109 \mathrm{bp}$ were produced. The $226 \mathrm{bp}$ fragment was not cleaved when the $\mathrm{G}$ allele was present.

Plasma separation and determination of IL-6 plasma levels. All patient blood samples were collected in K2EDTA tubes, to prevent clotting, in the morning between 7:00 am - 10:00 am after a night of fasting. All blood samples were examined in the same laboratory. Plasma samples were obtained immediately after blood collection by centrifugation at $2,000 \mathrm{r} / \mathrm{min}$ for $20 \mathrm{~min}$ at $4^{\circ} \mathrm{C}$, aliquoted to prevent freeze and thaw cycles and stored at $-80^{\circ} \mathrm{C}$ for later use. For determination of IL- 6 levels, plasma samples of 44 prostate cancer patients, 104 patients with BHP and 10 healthy men were collected and assessed using a commercially available ELISA kit.

Statistical analysis. Genotype frequencies were estimated for both patients with prostate cancer and BHP as well as for healthy controls. Comparisons between genotype distribution and association with selected clinical data were performed with the Chi-square test and Fisher's exact test. The genotype frequencies were tested for Hardy-
Table I. Characteristics of prostate cancer patients, BHP patients and healthy subjects.

\begin{tabular}{lccc}
\hline Characteristics & Healthy controls & Prostate cancer & BHP \\
\hline Age (years) & $58.15 \pm 9.48$ & $66.8 \pm 8.09$ & $66.12 \pm 9.45$ \\
$\begin{array}{l}\text { Mean } \pm \text { SD } \\
\text { PSA (ng/ml) }\end{array}$ & 0.88 & 9.18 & 2.36 \\
$\begin{array}{l}\text { Median } \\
\text { (25th-75th percentile) }\end{array}$ & $(0.48-2.27)$ & $(5.30-20.07)$ & $(0.89-6.09)$ \\
Gleason score & NA & $7.03 \pm 1.30$ & NA \\
Mean \pm SD & & & \\
\hline
\end{tabular}

NA: Not applicable.

Weinberg equilibrium in the control group. Comparison of IL-6 plasma levels between studied groups as well as their association with different genotypes was performed by Mann-Whitney test. All $p$ values were derived from two-sided tests and were considered to be statistically significant if $p<0.05$. Statistical analysis was performed using StatsDirect statistical package version 2.7.8.

\section{Results}

Genotype distribution of IL-6 -174 polymorphisms. Screening for the polymorphism in the IL-6 gene, rs1800795, located at the -174 position of the promoter region was performed in this study. The distribution of genotypes was in agreement with the Hardy-Weinberg equilibrium $(p=0.27)$ in the control group. Distribution of alleles and genotypes in the group of patients with prostate cancer, BHP as well as in the control group are summarized in Table II.

Statistically significant association of the -174 GC genotype $(\mathrm{OR}=0.61 ; 95 \% \mathrm{CI}=0.43-0.86 ; p=0.005)$ and $\mathrm{C}$ allele $(\mathrm{OR}=0.80 ; 95 \% \mathrm{CI}=0.64-0.99 ; p=0.04)$ with the decreased risk of prostate cancer development was observed. The association of the $I L-6-174$ polymorphism was significant also in the dominant model (GG versus $\mathrm{GC}+$ $\mathrm{CC})(\mathrm{OR}=0.63 ; 95 \% \mathrm{CI}=0.46-0.88 ; p=0.006)$. No significant association of IL-6 -174 polymorphism with the risk of BHP development was found. The association of the GC genotype of the IL-6 -174 polymorphism was on the border of the statistical significance $(p=0.08)$ if we compared genotype frequencies between prostate cancer patients and BHP patients. The results are summarized in Table II.

To detect a possible correlation between IL-6 -174 polymorphism and aggressiveness of prostate cancer, patients were stratified according to Gleason score (Gleason score $<7$ and Gleason score $\geq 7$ ). When compared to the control group, the GC genotype was significantly associated with a decreased risk of development of both low-grade (Gleason score $<7$ ) and high-grade (Gleason score $\geq 7$ ) carcinomas ( $\mathrm{OR}=0.48$; $95 \% \mathrm{CI}=0.30-0.76 ; p=0.006$ and $\mathrm{OR}=0.62 ; 95 \% \mathrm{CI}=0.41-0.94$; $p=0.02$, respectively). Results are summarized in Table III. 
Jurečeková et al: Interleukin-6 Polymorphism and Prostate Cancer

Table II. Distribution of the IL-6 -174 genotypes and alleles and their association with the risk of prostate cancer or BHP development.

\begin{tabular}{|c|c|c|c|c|c|c|c|c|c|}
\hline \multirow{2}{*}{$\begin{array}{l}-174 \mathrm{G} / \mathrm{C} \\
\text { Genotype }\end{array}$} & \multirow{2}{*}{$\begin{array}{c}\text { Healthy } \\
\text { controls } \\
n\end{array}$} & \multirow{2}{*}{$\begin{array}{c}\text { Prostate } \\
\text { cancer } \\
n\end{array}$} & \multirow{2}{*}{$\begin{array}{c}\text { BHP } \\
n\end{array}$} & \multicolumn{2}{|c|}{ Controls $v s$. Prostate cancer } & \multicolumn{2}{|c|}{ Controls vs. BHP } & \multicolumn{2}{|c|}{ BHP vs. Prostate cancer } \\
\hline & & & & OR (95\%CI) & $p$-Value & OR $(95 \% \mathrm{CI})$ & $p$-Value & OR $(95 \% \mathrm{CI})$ & $p$-Value \\
\hline GG & 78 & 171 & 121 & 1.00 (ref.) & & 1.00 (ref.) & & 1.00 (ref.) & \\
\hline GC & 147 & 197 & 184 & $0.61(0.43-0.86)$ & 0.005 & $0.81(0.57-1.15)$ & 0.24 & $0.76(0.56-1.03)$ & 0.08 \\
\hline $\mathrm{CC}$ & 51 & 78 & 71 & $0.70(0.45-1.09)$ & 0.11 & $0.90(0.57-1.42)$ & 0.64 & $0.78(0.52-1.16)$ & 0.21 \\
\hline $\begin{array}{l}\mathrm{GC}+\mathrm{CC} \\
\text { Allele }\end{array}$ & 198 & 275 & 255 & $0.63(0.46-0.88)$ & 0.006 & $0.83(0.60-1.17)$ & 0.28 & $0.76(0.57-1.02)$ & 0.07 \\
\hline G & 303 & 539 & 426 & 1.00 (ref.) & & 1.00 (ref.) & & 1.00 (ref.) & \\
\hline $\mathrm{C}$ & 249 & 353 & 326 & $0.80(0.64-0.99)$ & 0.04 & $0.93(0.75-1.16)$ & 0.53 & $0.86(0.70-1.04)$ & 0.12 \\
\hline
\end{tabular}

Statistically significant results $(p<0.05)$ are highlighted in bold.

Table III. Association between the IL-6 -174 genotypes and alleles in patients stratified according to Gleason score.

\begin{tabular}{|c|c|c|c|c|c|c|c|c|}
\hline \multirow{2}{*}{$\begin{array}{l}\text {-174 G/C } \\
\text { Genotype }\end{array}$} & \multicolumn{3}{|c|}{$\begin{array}{l}\text { Gleason } \\
\text { score }<7\end{array}$} & \multicolumn{3}{|c|}{$\begin{array}{l}\text { Gleason } \\
\text { score } \geq 7\end{array}$} & \multicolumn{2}{|c|}{$\begin{array}{c}\text { Gleason score }<7 v s \text {. } \\
\text { Gleason score } \geq 7\end{array}$} \\
\hline & $\mathrm{n}$ & OR $(95 \% \mathrm{CI})$ & $p$-Value & $\mathrm{n}$ & OR $(95 \% \mathrm{CI})$ & $p$-Value & OR $(95 \% \mathrm{CI})$ & $p$-Value \\
\hline GG & 53 & 1.00 (ref.) & & 76 & 1.00 (ref.) & & 1.00 (ref.) & \\
\hline GC & 48 & $0.48(0.30-0.76)$ & 0.006 & 89 & $0.62(0.41-0.94)$ & 0.02 & $1.29(0.79-2.124)$ & 0.31 \\
\hline $\mathrm{CC}$ & 26 & $0.75(0.42-1.35)$ & 0.34 & 39 & $0.79(0.47-1.32)$ & 0.36 & $1.05(0.57-1.92)$ & 0.88 \\
\hline $\begin{array}{l}\mathrm{GC}+\mathrm{CC} \\
\text { Allele }\end{array}$ & 74 & $0.55(0.35-0.85)$ & 0.007 & 128 & $0.66(0.45-0.98)$ & 0.04 & $1.21(0.77-1.90)$ & 0.42 \\
\hline $\mathrm{G}$ & 154 & 1.00 (ref.) & & 241 & 1.00 (ref.) & & 1.00 (ref.) & \\
\hline $\mathrm{C}$ & 100 & $0.79(0.58-1.07)$ & 0.13 & 167 & $0.84(0.65-1.09)$ & 0.20 & $1.07(0.78-1.47)$ & 0.69 \\
\hline
\end{tabular}

Statistically significant results $(p<0.05)$ are highlighted in bold.

Table IV. The plasma levels of IL-6 in prostate cancer patients, BHP and healthy controls.

\begin{tabular}{|c|c|c|c|c|c|c|}
\hline & Healthy controls & Prostate cancer & BHP & Controls $v s$. Prostate cancer & Controls vs. BHP & Prostate cancer $v s . \mathrm{BHP}$ \\
\hline $\begin{array}{l}\text { IL-6 }(\mathrm{pg} / \mathrm{ml}) \\
\text { (25th-75th percentile) }\end{array}$ & $\begin{array}{c}1.34 \\
(0.97-2.99)\end{array}$ & $\begin{array}{c}3.01 \\
(1.79-5.98)\end{array}$ & $\begin{array}{c}1.88 \\
(1.21-3.25)\end{array}$ & 0.02 & 0.28 & 0.008 \\
\hline
\end{tabular}

IL-6 plasma levels are given as medians. Statistically significant results $(p<0.05)$ are highlighted in bold.

IL-6 plasma levels and association with IL-6 -174 genotypes. IL-6 plasma levels were significantly elevated in prostate cancer patients in comparison to both healthy men $(p=0.02)$ as well as BHP patients $(p=0.008)$. Results are shown in Table IV. No association was observed between the presence of the $I L-6-174$ genotypes and IL-6 plasma levels (Table V).

\section{Discussion}

Polymorphisms located in the promoter region of the $I L-6$ gene can result in variations in transcription and influence the susceptibility to various diseases, including prostate cancer. In our study the association between -174 promoter polymorphisms of $I L-6$ and prostate cancer in Slovak patients was investigated. The importance of studying the particular polymorphism in different populations is underlined by the fact that there are important ethnic differences in the distribution of the -174 alleles. Bao et al. showed that, in Han people of China, there was no variation at the -174 position and all subjects have only the GG genotype (9). In this study, the GC genotype was significantly associated with decreased risk of prostate cancer development in Slovak prostate cancer patients. However, the polymorphism was not significantly associated with BHP. Similarly, to our results, Lopez et al. observed that $I L-6-174$ polymorphism is not associated with BHP (10). 
Table V. Association of IL-6 -174 genotypes with IL-6 plasma levels.

\begin{tabular}{lccccccc}
\hline & \multicolumn{3}{c}{ Genotypes and IL-6 levels $(\mathrm{pg} / \mathrm{ml})$} & & \multirow{2}{*}{ GG vs. GC } & GG vs. CC & GC vs. CC \\
\cline { 2 - 5 } IL-6 -174 G/C & \multicolumn{2}{c}{ GG } & \multicolumn{2}{c}{ GC } & & & \\
\hline Prostate cancer & $2.99(1.85-5.98)$ & $3.17(1.32-7.48)$ & $2.94(1.85-4.89)$ & & 0.85 & 0.82 & 0.89 \\
BHP & $1.83(1.21-4.27)$ & $2.03(1.26-3.02)$ & $1.50(1.06-2.97)$ & & 0.83 & 0.34 & 0.28 \\
\hline
\end{tabular}

IL-6 plasma levels are given as medians with 25 th-75th percentile range.

The previous studies on the association between $I L-6-174$ polymorphism and prostate cancer risk reported inconsistent results. Pierce et al. found an increased risk of prostate cancer associated with the $\mathrm{C}$ allele (11). The magnitude of this association was stronger in the more aggressive prostate carcinomas than in the less aggressive cases (11). Similarly, Tan et al. observed a significant association between this polymorphism and increased risk of prostate cancer. They also found that distribution of -174 genotypes was significantly different between stages T3-T4 and T1-T2 (12). On the other hand, Mandal et al. revealed that the GG genotype was associated with $72 \%$ higher risk of prostate cancer $(\mathrm{OR}=1.72, p=0.0257)$ compared to the $\mathrm{GC}$ and $\mathrm{CC}$ genotypes (13). In contrast, we observed a decreased risk of prostate cancer to be significantly associated with the presence of the GC or CC genotypes which points to the fact that the GG genotype is associated with an increased risk. The study in the North Indian population suggests that IL-6 -174 polymorphism is associated with a two-fold increase in the risk of progression to bone metastases (14). In contrast, there are also studies that found no significant association between $I L-6-174$ genotypes and overall risk of prostate cancer (15-19). Michaud et al. did not also observe any association of either $I L-6-174$ genotype with both early and advanced stage prostate cancer (15).

In addition to analysis of the $I L-6-174$ polymorphisms, we also observed that IL-6 plasma levels were significantly higher in prostate cancer patients in comparison to both healthy men and BHP patients. Similarly to our findings, Stark et al. observed that IL-6 levels are higher in prostate cancer patients. They found that pre-diagnostic IL-6 levels were significantly associated with the time of prostate cancer progression to metastatic disease or to death among healthy weight patients (16). However, it is assumed that IL-6 serum levels do not indicate the presence of metastasis, but rather that the tumor has the potential to metastasize (20). Alcover et al. also observed that preoperative levels of IL-6 were predictors of biochemical recurrence (21). Johnke et al. also detected higher IL-6 plasma concentrations in prostate cancer patients compared to healthy controls (22). On the other hand, Pierce et al. found no significant association between prostate cancer risk and blood IL-6 (11). Results of the study published by Yu et al. indicate that IL-6 is not produced by prostate adenocarcinoma cells. The expression of IL-6 mRNA is restricted, nearly exclusively, to the stromal compartment and is highly upregulated in areas of acute inflammation and prostatic atrophy. Therefore, it is assumed that IL-6 most likely signals in a paracrine fashion through IL-6 receptor and thus contributes to prostate cancer development and progression (23).

We also tried to assess if the observed increase in the IL-6 plasma levels was associated with the presence of -174 polymorphism in the promoter region of $I L-6$ gene, which has been reported to suppress gene transcription in vitro (5). Neither $I L-6-174$ genotype was associated with a significantly changed IL-6 plasma levels in our study. However, our results might be misleading, because a limited number of plasma samples was analyzed. Previous studies that examined the influence of this polymorphism on the levels of IL-6 presented conflicting results. Some confirmed our observation of no association $(16,24)$, but other described a change in IL-6 levels due to the presence of different $I L-6-174$ genotypes $(5,25)$. These conflicting results might be explained by the probability that more than one polymorphic sites in $I L-6$ gene are functional and influence $I L-6$ transcription (26).

In the presented study, a significant protective role of the GC genotype of $I L-6-174$ polymorphism was demonstrated in patients with prostate cancer. However, there are several limitations of our study. All cases and controls were selected from one hospital and, therefore may not ideally represent the general population. Chronic inflammation, considered as an important promoting factor of prostate cancer, is multifactorial and a complex process influenced by many other genetic factors. Therefore, our study offers only a partial insight into the process of prostate carcinogenesis.

\section{Acknowledgements}

This publication is the result of the project implementation, Biomedical Center Martin“ ITMS code: 26220220187, supported by the Operational Programme Research and Innovation funded by the ERDF, by the Agency of Ministry of Education, Science, Research, and Sport of the Slovak Republic under Grant VEGA No. 1/0172/18, by the grant APVV-15-0217 "The molecular mechanisms of the statins effect on inhibition, proliferation and differentiation of selected stem and tumour cells and their application in regenerative medicine." and grant UK/121/2018. 


\section{References}

1 Corcoran NM and Costello AJ: Interleukin-6: minor player or starring role in the development of hormone-refractory prostate cancer? BJU Int 91: 545-553, 2003.

2 Lee SO, Lou W, Hou M, de Miguel F, Gerber L and Gao AC: Interleukin-6 promotes androgen-independent growth in $\mathrm{LNCaP}$ human prostate cancer cells. Clin Cancer Res 9: 370-376, 2003.

3 Rojas A, Liu G, Coleman I, Nelson PS, Zhang M, Dash R, Fisher PB, Plymate SR and Wu JD: IL-6 promotes prostate tumorigenesis and progression through autocrine cross-activation of IGF-IR. Oncogene 30: 2345-2355, 2011.

4 Shariat SF, Andrews B, Kattan MW, Kim J, Wheeler TM and Slawin KM: Plasma levels of interleukin-6 and its soluble receptor are associated with prostate cancer progression and metastasis. Urology 58: 1008-1015, 2001.

5 Fishman D, Faulds G, Jeffery R, Mohamed-Ali V, Yudkin JS, Humphries S and Woo P: The effect of novel polymorphisms in the interleukin-6 (IL-6) gene on IL-6 transcription and plasma levels, and an association with systematic-onset juvenile chronic arthritis. J Clin Invest 102: 1369-1376, 1998.

6 Hobisch A, Rogatsch H, Hittmair A, Fuchs D, Bartsch G Jr., Klocker $\mathrm{H}$, Bartsch $\mathrm{G}$ and Culig $\mathrm{Z}$ : Immunohistochemical localization of interleukin- 6 and its receptor in benign, premalignant and malignant prostate tissue. J Pathol 191: 239-244, 2000.

7 Cole SW, Arevalo JMG, Takahashi R, Sloan EK, Lutgendorf SK, Sood AK, Sheridan JF and Seeman TE: Computational identification of gene-social environment interaction at the human IL6 locus. Proc Natl Acad Sci USA 107: 5681-5686, 2010.

8 Tumu VR, Govatati S, Guruvaiah P, Deenadayal M, Shivaji S and Bhanoori M: An interleukin-6 gene promoter polymorphism is associated with polycystic ovary syndrome in South Indian women. J Assist Reprod Genet 30: 1541-1546, 2013.

9 Bao S, Yang W, Zhou S and Ye Z: Relationship between single nucleotide polymorphisms in $-174 \mathrm{G} / \mathrm{C}$ and $-634 \mathrm{C} / \mathrm{G}$ promoter region on interleukin- 6 and prostate cancer. J Huazhong Univ Sci Technol 28: 693-696, 2008.

10 Lopez DS, Peskoe SB, Tsilidis KK, Hoffman-Bolton J, Helzlsouer KJ, Isaacs WB, Smith MW and Platz EA: Association of variants in genes related to the immune response and obesity with benign prostatic hyperplasia in CLUE II. Prostate Cancer Prostatic Dis 17: 353-358, 2014.

11 Pierce BL, Biggs ML, DeCambre M, Reiner AP, Li Ch, Fitzpatrick A, Carlson ChS, Stanford JL and Austin MA: C-reactive protein, interleukin-6, and prostate cancer risk in men aged 65 years and older. Cancer Causes Control 20: 1193-1203, 2009.

12 Tan D, Wu X, Hou M, Lee SO, Lou W, Wang J, Janarthan B, Nallapareddy S, Trump DL and Gao AC: Interleukin-6 polymorphism is associated with more aggressive prostate cancer. J Urol 174: 753-756, 2005.

13 Mandal S, Abebe F and Chaudhary J: -174G/C polymorphism in the interleukin- 6 promoter is differently associated with prostate cancer incidence depending on race. Genet Mol Res 13: 139151,2014

14 Keserwani P, Ahirwar DK, Mandhani A and Mittal RD: Association between $-174 \mathrm{G} / \mathrm{C}$ promoter polymorphism of the interleukin- 6 gene and progression of prostate cancer in North Indian population. DNA Cell Biol 27: 505-510, 2008.
15 Michaud DS, Daugherty SE, Berndt SI, Platz EA, Yeager M, Crawford ED, Hsing A, Huang WY and Hayes RB: Genetic polymorphisms of interleukin-1B (IL-1B), IL-6, IL-8, and IL-10 and risk of prostate cancer. Cancer Res 66: 4525-4530, 2006.

16 Stark JR, Li H, Kraft P, Kurth T, Giovannucci EL, Stampfer MJ, Ma J and Mucci LA: Circulating prediagnostic interleukin- 6 and C-reactive protein and prostate cancer incidence and mortality. Int J Cancer 124: 2683-2689, 2009.

17 Dossus L, Kaaks R, Canzian F, Albanes D, Berndt SI, Boeing H, Buring J, Chanock SJ, Clavel-Chapelon F, Feigelson HS, Gaziano JM, Giovannucci E, Gonzales C, Haiman ChA, Hallmans G, Hankinson SE, Hayes RB, Henderson BE, Hoover RN, Hunter DJ, Khaw KT, Kolonel LN, Kraft P, Ma J, Le Marchand L, Lund E, Peeters PH, Stampfer M, Stram DO, Thomas G, Thun MJ, Tjonneland A, Trichopoulos D, Tumino R, Riboli E, Virtamo J, Weinstein SJ, Yeager M, Ziegler RG and Cox DG: PTGS2 and IL6 genetic variation and risk of breast and prostate cancer: results from the Breast and Prostate Cancer Consortium (BPC3). Carcinogenesis 31: 455-461, 2010.

18 Mandić S, Sudarević B, Marczi S, Horvat V, Ćosić I, Mihaljević S, Miličević N, Šimunović D and Galić J: Interleukin-6 polymorphism and prostate cancer risk in population of Eastern Croatia. Coll Antropol 37: 907-911, 2013.

19 Chen CH, Gong M, YI QT and Guo JH: Role of interleukin-6 gene polymorphisms in the development of prostate cancer. Genet Mol Res 14: 13370-13374, 2015.

20 Brinton LT, Brentnall TA, Smith JA and Kelly KA: Metastatic biomarker discovery through proteomics. Cancer Genomics Proteomics 9: 345-355, 2012.

21 Alcover J, Filella X, Luque P, Molina R, Izquierdo L, Auge JM and Alcaraz A: Prognostic value of IL-6 in localized prostatic cancer. Anticancer Res 30: 4369-4372, 2010.

22 Johnke RM, Edwards JM, Evans MJ, Nangami GN, Bakken NTG, Kilburn JM, Lee TK, Allison RR, Karlsson UL and Arastu HH: Circulating cytokine levels in prostate cancer patients undergoing radiation therapy: influence of neoadjuvant total androgen suppression. In Vivo 23: 827-834, 2009.

$23 \mathrm{Yu} \mathrm{SH}$, Zheng Q, Esopi D, Macgregor-Das A, Luo J, Luo J, Antonarakis ES, Drake CG, Vessella R, Morrisey C, De Marzo AM and Sfanos KS: A paracrine role for IL6 in prostate cancer patients: lack of production by primary or metastatic tumor cells. Cancer Immunol Res 3: 1175-1184, 2015.

24 Margaglione M, Bossone A, Cappucci G, Colaizzo D, Grandone E and Di Minno G: The effect of interleukin-6 C/G -174 polymorphism and circulating interleukin-6 on fibrinogen plasma levels. Haematologica 86: 199-204, 2001.

25 Jones KG, Brull DJ, Brown LC, Sian M, Greenhalgh RM, Humphries SE and Powell JT: Interleukin-6 (IL-6) and the prognosis of abdominal aortic aneurysms. Circulation 103: 22602265, 2001.

26 Terry CF, Loukacis V and Green V: Cooperative influence of genetic polymorphisms on interleukin 6 transcriptional regulation. J Biol Chem 16: 18138-18144, 2000.

Received March 16, 2018

Revised April 26, 2018

Accepted April 30, 2018 